\title{
The Information Disclosure Strategy of Single versus Multiple Benchmarks in Earnings Announcements
}

\author{
SRI WAHYUNI* \\ STIE Mahardhika Surabaya \\ JOGIYANTO HARTONO \\ SUPRIYADI \\ ERTAMBANG NAHARTYO \\ Universitas Gadjah Mada
}

\begin{abstract}
This study is aimed to test the impact of single versus multiple benchmarks earnings information disclosure strategy towards financial users' behavior in estimating future earnings. The study is important because it links behavioral aspects between the ways of providing and using earnings information based on multiple reference point theory of psychology. Using experimental factorial mix design $2 \times 3 \times 2$ with 58 investor and non-investor participants, the result indicates that earnings disclosure strategy of single versus multiple benchmarks influences participant's judgments. Specifically, the multiple benchmarks are more effective than a single benchmark used to estimating future earnings. This finding is consistent with some priors studies of Schrand and Walther (2000), Krische (2005), Han and Tan (2007) and Wahyuni and Hartono (2010, 2012, 2014).
\end{abstract}

Keywords: Single Benchmark, Multiple Benchmarks, Multiple Reference Point Theory, Disclosure

Intisari: Penelitian ini bertujuan untuk menguji dampak strategi pengungkapan informasi pendapatan single versus multiple benchmark terhadap perilaku pengguna keuangan dalam memperkirakan pendapatan masa depan. Penelitian ini penting karena mengaitkan aspek perilaku antara cara menyediakan dan menggunakan informasi pendapatan berdasarkan teori psikologi titik rujukan ganda. Menggunakan desain faktorial campuran $2 \times 3 \times 2$ eksperimental dengan 58 investor dan non-investor peserta, hasilnya menunjukkan bahwa strategi pengungkapan pendapatan dari satu tolok ukur ganda mempengaruhi penilaian peserta. Secara khusus, beberapa tolok ukur lebih efektif daripada satu tolok ukur tunggal yang digunakan untuk memperkirakan penghasilan di masa depan. Temuan ini konsisten dengan beberapa penelitian sebelumnya dari Schrand dan Walther (2000), Krische (2005), Han dan Tan (2007) dan Wahyuni dan Hartono $(2010,2012,2014)$.

Kata Kunci: Tolok Ukur Tunggal, Tolok Ukur Ganda, Teori Titik Referensi Ganda, Pengungkapan

* Corresponding author: yuni71@yahoo.com 


\section{Introduction}

This study is aimed to test the impact of single versus multiple benchmarks earnings information disclosure strategy towards financial users' behavior in estimating future earnings. The disclosure strategy of single benchmark uses historical earnings as a reference (backward looking information). The multiple benchmarks disclosure strategy uses backward-looking information (historical earnings) and forward-looking information (management earnings forecast or management guidance) as a reference in business decision making. This study tries to develop the previous studies by focusing on multiple reference point theory for testing the single versus various benchmarks earnings information disclosure strategy. Different from the study by Schrand and Walther (2000), Krische (2005) and Wahyuni and Hartono (2011) who have conducted testing on benchmark disclosure strategy of a prior period in the earnings announcement. Those researches use a single reference point in evaluating company's performance which only has one dimension of time shown by considering only backward-looking information in term of earnings from the prior period in the present earnings announcement.

The primary purpose of this study is to test whether the financial user uses multiple reference points of information for estimating future earnings. This research tests the effectiveness of the various benchmarks' earnings information disclosure strategy on the investors' behavior in estimating future earnings. Multiple reference point theory from psychology (Fiegenbaum et al., 1996; Ordones et al., 2000) predicts that in a complex environment, an individual is affected by three main dimensions in making a business decision which are internal, external and time (past, present, and future) dimensions. Therefore, this study tries to use multiple reference point that does not only focus on time, but also includes a psychological factor which is considering backward-looking information and forward-looking information, as well as a psychological factor. The involvement of psychological aspect is in line with Bernard (1989) and Hartono (2004) who supported that the research should adopt a new way to think market by considering a cognitive-psychological aspect. 
This study is testing a disclosure strategy of single benchmark use historical earnings which includes nonrecurring events (prior-period gain/loss on sale of fixed assets). There are some reasons why this study is considering historical earnings which include non-recurring events. First, gain/loss on sale of fixed assets information is nonrecurring events, so it is crucial information when evaluating company's performance (Schrand and Walther, 2000; Krische, 2005; Wahyuni and Hartono, 2012). Second, the adjustment is also justified because persistent earnings, which is betterrepresented prior-period adjusted earnings should receive more weight than nonrecurring information in estimating future earnings (Foster, 1977; Kormendi and Lipe, 1987; Eston and Zmijewski, 1989; and Freeman and Tse, 1992).

There is some evidence suggest that non-recurring events is essential information when evaluating company's performance. For example, The Wall Street Journal (Bailey, 1997) criticized Wasted Management when they disclosed in 1997 that 1996 earnings had included non-recurring items and that these at the time. Similarly, Coca-Cola announced that third-quarter net income for 1998 was flat compared to 1997 once gained from bottling transactions in 1998 and 1997 were eliminated, even though net income had actually decreased (Lowenstein, 1997; Deogun, 1998).

Testing the disclosure strategy of multiple benchmarks uses historical earnings and future information (management earnings forecast or management guidance). Future information can be earnings forecast information that is both made by analyst known as analyst earnings forecast and earnings forecast made by management known as management earnings forecast or management guidance. King et al., (1990) defined management earnings forecast as voluntary managerial disclosure that is an earnings prediction towards expected reporting. Widely, Baginski et al. (2004) stated that management often explains its earnings forecast through an attribution related to estimation performance both for company's internal activities (e.g., product and service issues, organizational issues) and company's external activities (e.g., economy conditions, or government regulations). Attribution is more possible for large private companies rather than state-owned companies (regulated). The attribution potentially helps the investor in interpreting management forecast, even more, possible for the 
negative estimates (bad news forecast). Not only the management guidance contains information (Patell, 1976; Penman, 1980; Waymire, 1984), but also seen to have quality information foreseeable future better than the analyst forecast (Ajinkya and Gift, 1984; Patell, 1976; Baginski et al., 2004). Therefore, information about the future in this study using information management guidance (Hartono and Wahyuni, 2014).

There are some reasons why this study is essential. First, study about earnings information disclosure strategy of single versus multiple benchmarks is including psychological aspect, so that contributes in behavioral aspects of accounting literature. Second, to respond to the existence of real phenomena about varied earnings information disclosure, in which some companies present the mandatory information and some companies present mandatory and voluntary information. Third, to test multiple reference point theory of psychology. Fourth, there is limited support for a theoretical and empirical study about the effectiveness of earnings information disclosure strategy. Fifth, the experiment design in this study will be the reference for the next researches.

This study is organized into several parts. Part 1 is started with the introduction. Part 2 explains the theoretical base and hypothesis development. Part 3 and part 4 describes the experimental method and the result. Part 5 elaborates the discussion of this research result and exposes the shortcomings of this research and suggestions for future research.

\section{Theoretical Framework and Hypothesis Development}

\subsection{Multiple Reference Point Theory}

Multiple reference point theory is one of the psychology theories developed through both concept and strategic reference point (SRP) practice known as a strategic benchmark (figure 2.1). In psychology research, benchmarks are called as comparison level (Thibaut and Kelley, 1959), adjustment level (Helson, 1964), or reference point (Kahneman and Tversky, 1979; Tversky, 1972).

Fiegenbaum et al., (1996) explained that strategic reference point is the company's choice in helping to reach strategic alignment. Strategic alignment is suitability between 
the expected external environment condition and internal ability owned by the company. SRP is developed from three dimensions, they are: 1) company's internal condition, 2) company's external condition and 3) time dimension that is oriented to past, present, and future time (figure 1).

Picture 1

Strategic Reference Point Matrix

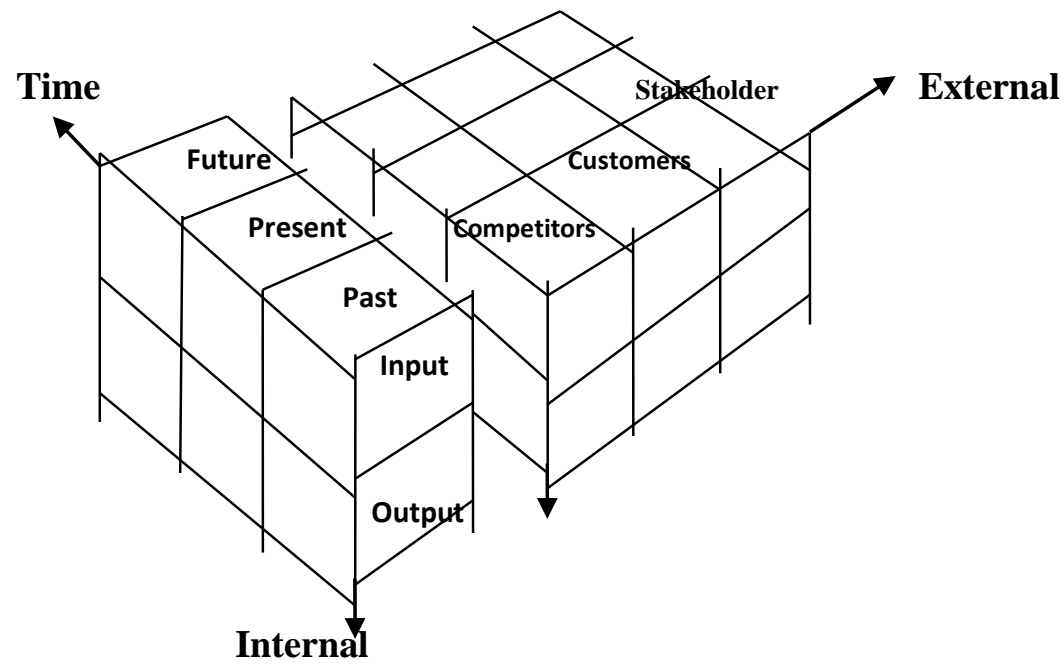

Source: Fiegenbaum et al., (1996) "Strategic Reference Point Theory."

SRP is built and developed from other relevant prospect and theoretical perspective theories. Kahneman and Tversky (1979) demonstrated prospect theory that an individual uses a target or reference point in evaluating choice. Individual behavior depends on how they feel themselves as if they are above (better) or below (worse) a special target or reference point they choose. Fiegenbaum and Thomas (1988) used prospect theory to describe behavior in company level. They found that an organization behaves as risk-seeking when it is below target or reference point, but as risk-averse when it is above the reference point.

\subsection{Single Benchmark Disclosure Strategy}

Schrand and Walther (2000) examine the strategic prior-period benchmark disclosures in the earnings announcement. The finding indicates that managers 
strategically select the amount of prior-period gain in quarterly earnings announcement and managers would prefer to announce prior-period gain separately from the sale of property, plant, and equipment than suffering loss. The assumption that underlies this phenomenon is the presence of bounded rationality (Bazerman, 1994) so that the priorperiod occurrence will naturally be forgotten by the investors, except when the information is disclosed in the current announcement. Thus, if the phenomenon is associated with reminder effect (Schrand and Walther, 2000; Krische, 2005; and Wahyuni and Hartono, 2010), indicate that investors will process the prior-period event revealed in current announcements information between gain and loss differently. It is believed that information about transitory prior-period gain will tend to encourage investors to behave more favorably, while information about transitory prior-period loss tends to persuade investors to act less favorably in evaluating performance.

Availability is deduced from heuristic concept (Simon, 1957; Kahmeman and Tversky, 1979). The availability view that individuals tend to make the decision based on the information in which exists their memories. Generally, information available in an individual's memory is the outstanding, or the most-frequently exposed one. Based on this assumption, it can be explained that the quantitative description of prior-period gain or loss exposed in the current earnings announcement will secure investors to have sufficient information in their memory and can be of much help for an individual in calculating the adjusted earnings (Krische, 2005; Wahyuni and Hartono, 2012). Boldt (2001) saw that individual behaves more/less favorable because the fixation effect which is when historical earnings contain loss/profit transitory, then, he/she would be immobilized to estimate future earnings higher/lower than current earnings.

Disclosing of prior-period gain/loss on sale of fixed assets, in general, is revealed in the current earnings announcement, but the specification for additional information (quantitative description) on prior-period gain/loss is the policy of the manager. Without any mention the prior-period gain or loss on sale of fixed assets in the current announcement, investors must recall the details of the gain or loss from long-term memory to adjust earnings (Moeckel, 1990; Schrand and Walther, 2000, Krische, 2005). 
The quantitative description of the of prior-period gain/loss in current earnings announcement is believed that investor will have additional information and wider consideration, so it can strengthen investor trust to give judgment in performance evaluation process. Therefore, when disclosure strategy of single benchmark uses historical earnings which includes nonrecurring events can influence investor's judgment. The formulation of this hypothesis is stated as follows:

H1. The subject will estimate the future earnings more positively when considering positive information of historical earnings and quantitative description which are included in the current-period announcement, rather than that negative information disclosure.

\subsection{Benchmarks Disclosure Strategy}

This research tests the effectiveness of multiple benchmarks disclosure strategy earnings information disclosure strategy on the investors' behavior in estimating future earnings. The primary purpose of this study is to test whether investors use multiple reference points of information for estimating future earnings. Multiple reference point theory from psychology (Fiegenbaum et al., 1996; Ordones et al., 2000) predicts that in a complex environment, an individual is affected by three main dimensions in making a business decision which is internal, external and time (past, present, and future) dimensions. The underlying assumption is the presence of bounded rationality (Bazerman, 1994), which is the condition of an individual who has limitations of information, time, memory capacity and others, so that the prior-period occurrence will naturally be forgotten and individual by the investor, except when the information is disclosed in the current announcement.

This study tries to develop the previous studies by focusing on multiple reference point theory for testing various benchmarks earnings information disclosure strategy. Different from the study by Schrand and Walther (2000), Krische (2005) and Wahyuni and Hartono (2011) who have conducted testing on benchmark disclosure strategy of a prior period in the earnings announcement. Those researches use a single reference point in evaluating company's performance which only has one dimension of time 
shown by considering only backward-looking information in term of earnings from the prior period in the present earnings announcement. This study tries to develop the previous studies by focusing on multiple reference point theory. Specifically, this study tests investors' behavior toward earnings announcement that considers internal, external and time (past, present, and future) dimensions.

Based on the multiple reference theory that states additional information will add more consideration for managers to make better decision making, additional prospectus information is also beneficial for managers. As results, prospectus information as an addition to the historical earnings information will enhance managers' decision making. Therefore, in earnings announcement, when the information of quantitative description of prior-period gain, and management guidance are included in the current-period announcement, investors will evaluate company's performance better than that negative information of additional information.

Quantitative description and predicted earnings information are disclosed in the earnings announcement are expected to affect the perception of investors who would then be reflected in their behavior when they are making business decisions. Therefore, this study predicts that investors will find it easier to estimate future earnings when the qquantitative description and predicted earnings information are disclosed in the earnings announcement. Thus, presenting the prospectus information necessary to evaluate the company's performance and provide benefits over time and cost efficiency. The following is the formulation hypothesis.

H2. Subjects with multiple benchmarks disclosure strategy will estimate future earnings more positively than using a single benchmark disclosure strategy in earnings announcements.

\section{RESEARCH METHODS}

\subsection{Experiment Design}

This research uses an experimental factorial mix design $2 \times 3 \times 2$ with 58 investor and non-investor participants. The $2 \times 3 \times 2$ experiment method in this research includes: (1) manipulated between subjects to be either positive information or negative information, 
(2) manipulated between subjects to characteristic of information disclosure at three levels: Earnings, Earnings + Description, and Earnings + Description + Management Guidance, and (3) manipulated within subject to estimation at two different announcements: initial and revised estimations. The experiment in this study with a $2 \mathrm{x}$ 3 x 2 mixed factorial design as seen in Table 1 .

Table 1

Experiment Design $2 \times 3 \times 2$

\begin{tabular}{cllcc}
\hline No & $\begin{array}{l}\text { Estimation } \\
\text { Stage }\end{array}$ & \multicolumn{1}{c}{ Characteristic of Information Disclosure } & \multicolumn{2}{c}{ Charge Information } \\
& & Positive & Negative \\
\hline 1 & Initial & Eamings & Sel 1a & Sel 4a \\
& Revised & Eamings + Internal MG & Sel 1b & Sel 4b \\
2 & Initial & Eamings + Description & Sel 2a & Sel 5a \\
& Revised & Eamings + Description + Internal MG & Sel 2b & Sel 5b \\
3 & Initial & Eamings + Description + Internal MG & Sel 3a & Sel 6a \\
& Revised & Eamings + Description + Internal MG + Exsternal MG & Sel 3b & Sel 6b \\
\hline
\end{tabular}

\subsection{Research Variables and Their Measurements}

In this experiment, the dependent variable is investors' estimation on the future earnings measured by investors' earnings forecast. Investors are asked to interpret earnings announcement, then make earnings forecast for the next year. The use of the earnings forecast as the measurement of investor's estimation is because earnings forecast are important components in determining a company's value (Feltham \& Ohlson, 1995; Ohlson 1995).

Independent variables in this study are factors from $2 \times 3 \times 2$ mixed design treatment. The $2 \times 3 \times 2$ experiment method in this research includes: (1) manipulated between subjects to be either positive information or negative information, (2) manipulated between subjects to characteristic of information disclosure at three levels: Earnings, Earnings + Description, and Earnings + Description + Management Guidance, and (3) manipulated within subject to estimation at two different announcements: initial and revised estimations. Within-subject measures sources of information dimension (two levels: single benchmark and multiple benchmarks). In this study, the disclosure strategy of single benchmark uses historical earnings as a reference (backward looking 
information). The various benchmarks disclosure strategy uses backward-looking information (historical earnings) and forward-looking information (management earnings forecast or management guidance).

\subsection{Experiment Participants}

Participant criteria in this research are to know the 1) field of investment, 2) stock market, and 3) financial reporting analysis. Based on those criteria, then, participants in this research include (1) investors, and (2) non-investor who have committed investment activities and knew the field of investment, capital market, and financial statement analysis. The experiment is done by using paper-based experiment.

\subsection{Experiment Task and Procedure}

This experiment uses materials from the study of Krische (2005) with a little adjustment in context story to make it more realistic to the setting in Indonesia. Each participant is given a written instruction and material case. All participants had access to a calculator. The case setting is a manufacturing company producing snacks which the name is PT BINA KARYA MANDIRI, Tbk (PT BKM SNACK FOOD). The essence of this scenario is to make future earnings estimation based on the strategy disclosure of single versus multiple benchmarks in the earnings announcement. There are five steps in this experiment as explained in figure 2.

\subsection{Manipulation Check}

A manipulation check was performed to evaluate the subject's understanding of the experiment case material. In this experiment, the manipulation check is done after treatment. The manipulation check instructed subjects to determine the information used as a basis for evaluating company's performance according to with earnings information characteristics disclosure they received. Furthermore, subjects were asked to estimate future earnings and interpret the estimation magnitude that they made, are higher / lower than current earnings. The estimation magnitude is said higher when there is an increase Rp10, 000.00 or multiples and it is said lower if there is a decrease Rp10.000, 
00 or multiples thereof. If the subject does not answer as instructed, then the subject was declared not qualify in check manipulations.

Picture 2

Experiment Manipulation and Material

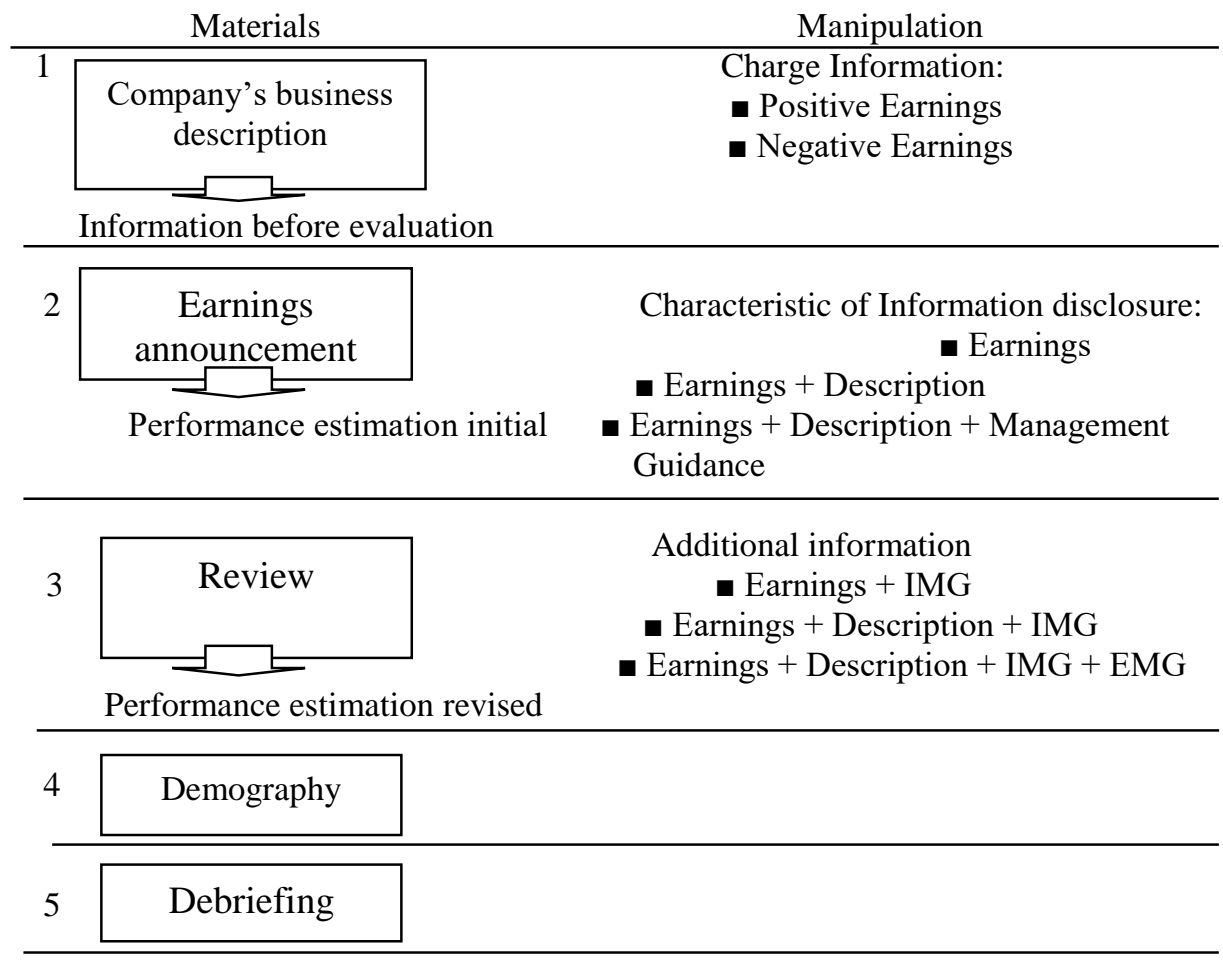

\subsection{Data Analysis and Hypothesis Testing}

Data analysis technique used in this experiment is an analysis of variance (ANOVA), ANCOVA, Univariate analyses of variance and independent sample t-test. The steps are performed in data analysis, and hypothesis testing include 1) testing the different characteristics of subjects with ANOVA analysis, 2) testing the effectiveness of randomization with ANOVA, 3) testing error experimental form of understanding and knowledge of the subject with ANCOVA, 4) testing experimental design factorial $2 \times 3 \times 2$ the univariate analysis, and 5) hypothesis testing and sensitivity by using 
independent sample t-test. The following is the hypothesis testing shown in table 2 below.

Table 2

Hypotheses Testing

\begin{tabular}{|c|c|c|}
\hline No & Hypotheses & Testing Ways \\
\hline 1 & $\begin{array}{l}\text { H1: Single Benchmark } \\
\text { Disclosure Strategy. }\end{array}$ & $\begin{array}{l}\text { (Cell 2a) Vs (Cell 5a): Comparing effects of Earnings + } \\
\text { Desc (positive) with Earnings + Desc (negative). } \\
\text { (Cell 2b) vs (Cell 5b): Comparing effects of Earnings + } \\
\text { Desc + IMG (positive) with Earnings + Desc + IMG } \\
\text { (negative). }\end{array}$ \\
\hline 2 & $\begin{array}{l}\text { H2: } \text { Multiple Benchmarks } \\
\text { Disclosure Strategy }\end{array}$ & $\begin{array}{l}\text { (Cell 3a) Vs (Cell 6a): Comparing effects of Earnings + } \\
\text { Desc + IMG (positive) with Earnings + Desc + IMG } \\
\text { (negative). } \\
\text { (Cell 3b) Vs (Cell 6b): Comparing effects of Earnings + } \\
\text { Desc + IMG + EMG (positive) with Earnings + Desc + IMG } \\
+ \text { EMG (negative) }\end{array}$ \\
\hline & $\begin{array}{l}\text { H2: Single Benchmark vs. } \\
\text { Multiple }\end{array}$ & $\begin{array}{l}\text { (Cell 2a) Vs (Cell 3a): Comparing effects of Earnings + } \\
\text { Desc (positive) }\end{array}$ \\
\hline & Benchmarks & $\begin{array}{l}\text { with Earnings + Desc + IMG (positive) } \\
\text { (Cell 2b) Vs (Cell 3b): Comparing effects of Earnings + } \\
\text { Desc + IMG (positive) with Earnings + Desc + IMG + EMG } \\
\text { (positive) } \\
\text { (Cell 5a) Vs (Cell 6a): Comparing effects of Earnings + } \\
\text { Desc (negative) with Earnings + Desc + IMG (negative). } \\
\text { (Cell 5b) Vs (Cell 6b): Comparing effects of Earnings + } \\
\text { Desc + IMG (negative) with Earnings + Desc + IMG + } \\
\text { EMG (negative) }\end{array}$ \\
\hline
\end{tabular}

\section{Research Result}

\subsection{Characteristic of the Data and Subject Demography}

Experiments were done by using approach-based personnel on a voluntary basis and the willingness of the subject. Recruitment is done through cooperation with the stock exchanges, educational institutions, and various relationships. Personnel approach makes it easy for the subject because the subject can determine the time and place in accord with the desired so that the time and place of execution of the experiment be varied.

Subjects in this study randomly were assigned to six groups of experiments that three group received positive earnings information and another group received negative 
earnings information. Randomization is performed that each subject received the same opportunity to occupy each experimental group. In this study, participants were 64 people, but six people were declared fail in check manipulations so that the total participants numbered fifty-eight (58) persons. Fifty-eight (58) subjects consisted of twenty-eight (28) the investor and thirty (30) the non-investor. Participants included 26 men and 32 women. The subjects have an average age of 28 years. Participants were randomly grouped into six groups as follows.

Table 3

Descriptive Statistics of Participant Categories

\begin{tabular}{ccccc}
\hline Group & Earnings & $\begin{array}{c}\text { Earnings + } \\
\text { Description }\end{array}$ & $\begin{array}{c}\text { Earnings + } \\
\text { Description + } \\
\text { MG }\end{array}$ & Total \\
\hline Positive & 8 & 9 & 12 & 29 \\
Negative & 10 & 10 & 9 & 29 \\
\hline Total & 18 & 19 & 21 & 58 \\
\hline
\end{tabular}

Subject characteristics differences are not expected to affect the determination of the estimated future earnings as indicated by the test results ANOVA with dependent variable estimated earnings and the independent variable demographic characteristics (gender, age, education, profession and job duration, as well as the time difference) in Table 4

\subsection{Experimental Error Testing}

Statistical testing using ANCOVA to reduce other factors that may affect the causal relationship into experimental error. Another factor that may influence the independent relationship variables of charge information and characteristics disclosure with the dependent variable of initial estimate is the value of information disclosure usefulness understanding and disclosure strategy effectiveness (Knowledge Score). The following ANCOVA test results for the initial estimate is shown in Table 5, and revised estimates are shown in Table 6. 
Table 4

Demographic Characteristics and Time Difference Testing to Estimation

\begin{tabular}{llll}
\hline Independent Variable & df & F-Statistic & Sig. \\
\hline Panel A: The Impact of Demographic toward & & & \\
$\quad$ Initial Estimation & 1 & 0.085 & 0.772 \\
Gender & 2 & 0.308 & 0.736 \\
Age & 2 & 0.301 & 0.741 \\
Education & 1 & 1.182 & 0.282 \\
$\quad$ Profession & 3 & 1.174 & 0.328 \\
$\quad$ Job Duration & & & \\
Panel B: The Impact of Time Difference to & 1 & 0.085 & 0.772 \\
Initial $\quad$ Estimation & & & \\
$\quad$ Time Difference & 1 & & \\
Panel C: The Impact of Demographic toward & & 0.064 & 0.800 \\
$\quad$ Revised Estimation & 2 & 0.303 & 0.740 \\
$\quad$ Gender & 2 & 0.205 & 0.815 \\
$\quad$ Age & 1 & 1.067 & 0.306 \\
$\quad$ Education & 3 & 1.047 & 0.379 \\
$\quad$ Profession & & & \\
$\quad$ Job Duration & 1 & 0.064 & 0.800 \\
Panel D: The Impact of Time Difference to & & & \\
Revised $\quad$ Estimation & & & \\
$\quad$ Time Difference &
\end{tabular}

Table 5

The result of ANCOVA (Initial Estimation)

\begin{tabular}{llllll}
\hline $\begin{array}{l}\text { Independence } \\
\text { Variable }\end{array}$ & $\begin{array}{l}\text { Type III } \\
\text { Sum of } \\
\text { Square }\end{array}$ & df & Mean Square & F & Sig. \\
\hline $\begin{array}{l}\text { Charge Information } \\
(\mathrm{CI})\end{array}$ & $976,619.485$ & 1 & $976,619.485$ & 1.250 & 0.000 \\
$\begin{array}{l}\text { Disclosure } \\
\text { Characteristics (DC) }\end{array}$ & $203,258.681$ & 2 & $101,629.340$ & 13.017 & 0.000 \\
CI * DC & $378,918.210$ & 2 & $189,459.105$ & 242.667 & 0.000 \\
Score of Knowledge & $168,444.09$ & 1 & $168,444.09$ & 0.216 & 0.644 \\
\hline
\end{tabular}


Table 6

The result of ANCOVA (Revised Estimation)

\begin{tabular}{llllll}
\hline $\begin{array}{l}\text { Independence } \\
\text { Variable }\end{array}$ & $\begin{array}{l}\text { Type III } \\
\text { Sum of } \\
\text { Square }\end{array}$ & df & Mean Square & F & Sig. \\
\hline Charge Information & $1,999.000$ & 1 & $1,999.000$ & $2,155.6$ & 0.000 \\
$\begin{array}{l}\text { Disclosure } \\
\text { Characteristics }\end{array}$ & $644,331.093$ & 2 & $322,165.546$ & 34.748 & 0.000 \\
CI * DC & $506,638.706$ & 2 & $253,319.353$ & 273.226 & 0.000 \\
Score of Knowledge & $202,686.251$ & 1 & $202,686.251$ & 2.186 & 0.145 \\
\hline
\end{tabular}

Table 5 ANCOVA results show that the charge information and disclosure characteristics as independent variables influence the determination of the initial and revised estimates with a significance value of $\mathrm{p}=0.000$, while subject's value of understanding and knowledge as covariate variable does not affect the initial estimate with $\mathrm{F}=0.216$ and $\mathrm{p}=0.644$. Likewise, Table 6 shows that the charge information and disclosure characteristics influence on revised estimates with a significance value of 0.000, while subject's value of understanding and knowledge does not affect the revised estimates with significant value 0.145 . The conclusion of this test is the subject's value of understanding and knowledge does not affect the relationship between charge information and disclosure characteristics by the determination of the initial and revised estimates.

\subsection{Hypothesis Testing}

\subsubsection{Preliminary Analysis}

Before investigating a specific hypothesis, this study applies the model mix factorial design $2 \times 3 \times 2$ with analysis of variance (ANOVA). The ANOVA testing results showed Initials-Between Groups ( $\mathrm{F}=381.597$; Sig. $=0.000)$, while RevisionBetween Group ( $\mathrm{F}=567.534$; Sig. $=0.000)$. Results of analysis of variance reflect differences in response or subjective probabilities are statistically significant intergroup treatments related to estimated future earnings both for the initial estimate and for revised estimates. The big difference in the response indicates that the characteristics 
and content of information disclosure affect the behavior of investors in estimating future earnings.

In Table 4.5, it is explained that the subject's response in the group of positive information has a higher mean than the subject's response in the group of negative information. Subjects response positively for positive information. Subjects response positively from $\mathrm{Rp538,750}$ to Rp552,222 for positive earnings information + description, then increase to $\mathrm{Rp} 586,667$ for positive earnings + description + MG. Subjects response negative from $\mathrm{Rp} 511,000$ to $\mathrm{Rp} 483,000$ for negative earnings information + description, decrease to Rp433,889 for negative earnings + description + MG. The subject's response in this study can be interpreted that the subject who consider positive information of historical earnings and management guidance estimating future earnings higher than in subjects who consider negative information. Difference estimation subjects in this study were statistically significantly below one percent $(p=0.000)$. Likewise, the subject's response to the revised estimates shown in Table 7.

Table 7

Subject' Mean Earnings Estimation (Standard Deviation)

\begin{tabular}{llrrr}
\hline GROUP & $\begin{array}{l}\text { Estimation } \\
\text { Stage }\end{array}$ & Earnings & $\begin{array}{c}\text { Earnings+ } \\
\text { Description }\end{array}$ & $\begin{array}{c}\text { Earnings + } \\
\text { Description } \\
+ \text { MG }\end{array}$ \\
\hline Positive & Initial & $538,750.00$ & $552,222.00$ & $586,667.00$ \\
& & $(6,408.70)$ & $(6,666.67)$ & $(8,876.25)$ \\
& Revised & $552,500.00$ & $565,556.00$ & $598,333.00$ \\
& & $(7,071.06)$ & $(8,819.17)$ & $(11,146.40)$ \\
\hline Negative & Initial & $511,000.00$ & $483,000.00$ & $433,889.00$ \\
& & $(5,163,98)$ & $(12,292.72)$ & $(10,540.92)$ \\
& Revised & $497,000.000$ & $462,000.00$ & $399,444.00$ \\
& & $(6,324.55)$ & $(12,516.65)$ & $(10,137.93)$ \\
\hline
\end{tabular}

Subject' future earnings estimation in this study is a dependent variable that is influenced by independent variables are charge information, characteristics disclosure, and additional information. The average Subject' future earnings estimation both at the initial and revised estimation can be seen in the chart below 1 . 
Chart 1

Subject' Mean Earnings Forecast for Initial and Revised Estimation.

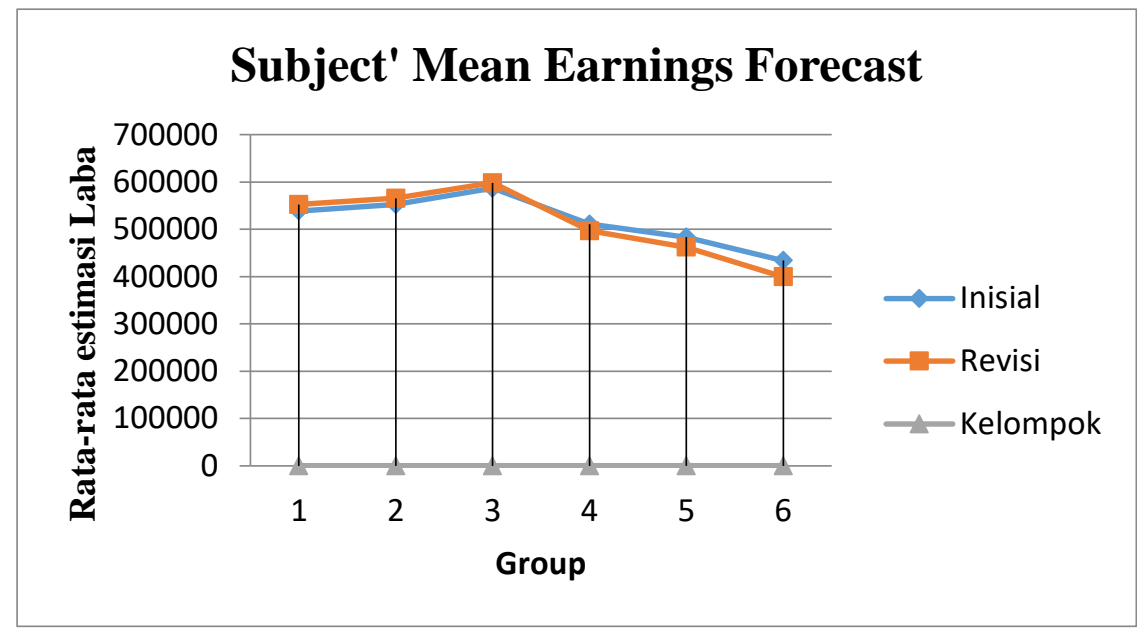

\subsubsection{Hypothesis Testing}

\subsubsection{Hypothesis Testing of Single Benchmark Disclosure Strategy}

The results of a single benchmark disclosure strategy hypothesis (H1) using independent sample t-test can be described in table 8 below.

Table 8

Hypothesis Testing of Single Benchmark Disclosure Strategy

\begin{tabular}{|c|c|c|c|c|c|c|}
\hline & \multirow[t]{2}{*}{ Mean } & \multirow[t]{2}{*}{$\begin{array}{c}\text { Mean } \\
\text { Difference }\end{array}$} & \multicolumn{2}{|c|}{$\begin{array}{l}\text { Levene's } \\
\text { Test }\end{array}$} & \multicolumn{2}{|c|}{$\begin{array}{l}\text { Independent } \\
\text { T-Test }\end{array}$} \\
\hline & & & $\mathrm{F}$ & Sig. & $\mathrm{t}$ & Sig. \\
\hline Initial Group: & & & & & & \\
\hline $\begin{array}{l}\text { E+Desc (Positive) vs } \\
\text { E+Desc (Negative) }\end{array}$ & $552,222>483,000$ & 69,222 & 3.942 & 0.063 & 15.459 & $0.000 *$ \\
\hline Revised Group: & & & & & & \\
\hline $\begin{array}{l}\mathrm{E}+\mathrm{Desc}+\mathrm{IMG} \text { (Positive) vs } \\
\mathrm{E}+\mathrm{Desc}+\mathrm{IMG} \text { (Negative) }\end{array}$ & $565,556>462,000$ & 103,556 & 1.728 & 0.206 & 21.004 & $0.000 *$ \\
\hline
\end{tabular}

Note: Significant at 0,05 .

\subsubsection{Hypothesis Testing of Multiple Benchmarks Disclosure Strategy}

The results of multiple benchmarks disclosure strategy hypothesis $(\mathrm{H} 2)$ using independent sample t-test can be described in table 9 below. 
Table 9

Hypothesis Testing of Multiple Benchmarks Disclosure Strategy

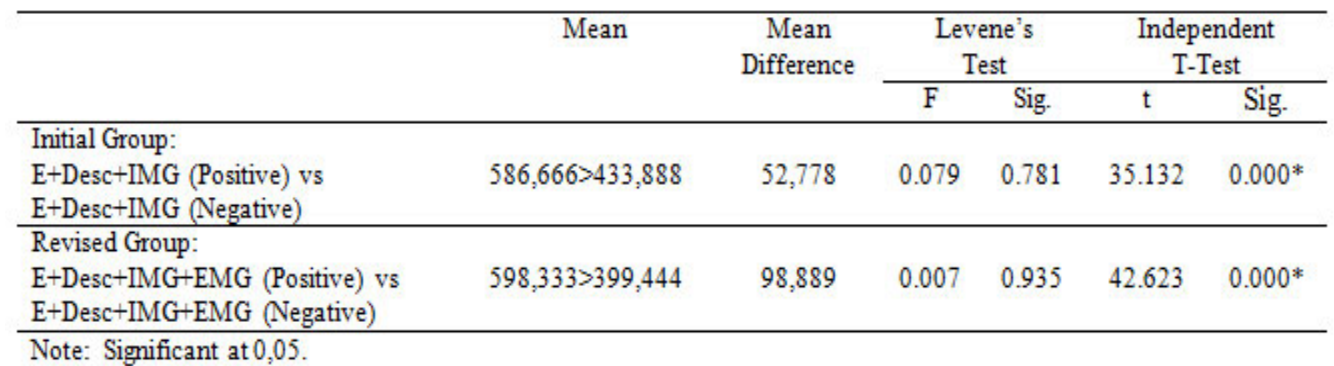

Table 9 shows that the subject's response to the dependent variable initial estimate that the positive earnings + description + internal management guidance group had a mean of 586.667 higher than the subject's response to the negative earnings + description + internal management guidance group which have a mean of only 433.888 . Results of t-test using independent sample t-test showed t value of 35.132 and $\mathrm{p}=0.000$. The difference subject's response was statistically significant under one percent $(\mathrm{p}=0.000)$, which means that the subject considering internal, external and time dimension in estimating future earnings. Thus hypothesis 2 is supported.

Likewise, the subject's response to the revised estimates shown that the positive earnings + description + internal management guidance + external management guidance group had a mean of 598.333 higher than the subject's response to the negative earnings + description + internal management guidance + external management guidance group which have a mean of only 399.444. Results of t-test using independent sample t-test showed t value of 42.623 and $\mathrm{p}=0.000$. The difference subject's response was statistically significant under one percent $(\mathrm{p}=0.000)$, which means that the subject considering internal, external and time dimension in estimating future earnings. Thus hypothesis 2 is supported.

In detail how the impact of single versus multiple benchmarks earnings information disclosure strategy towards financial users' behavior in estimating future earnings, this study conducted further testings as in table 10 below. 
Table 10

Effectiveness Testing Of Multiple Benchmarks Disclosure Strategy for Positive Information

\begin{tabular}{|c|c|c|c|c|c|c|}
\hline & \multirow[t]{2}{*}{ Mean } & \multirow[t]{2}{*}{$\begin{array}{c}\text { Mean } \\
\text { Difference }\end{array}$} & \multicolumn{2}{|c|}{$\begin{array}{c}\text { Levene's } \\
\text { Test }\end{array}$} & \multicolumn{2}{|c|}{$\begin{array}{l}\text { Independent } \\
\text { T-Test }\end{array}$} \\
\hline & & & F & Sig. & $t$ & $\mathrm{Sig}$. \\
\hline $\begin{array}{l}\text { Initial Group: } \\
\text { E+Desc (Positive) vs } \\
\text { E+Desc+IMG (Positive) }\end{array}$ & $552,222<586,667$ & 34,445 & 1.144 & 0.298 & -10.155 & $0.000 *$ \\
\hline $\begin{array}{l}\text { Revised Group: } \\
\text { E+Desc+IMG (Positive) vs } \\
\text { E+Desc+IMG+EMG (Positive) }\end{array}$ & $565,556<598.333$ & 32,777 & 0.322 & 0.577 & -7.521 & $0.000 *$ \\
\hline
\end{tabular}

Results in Table 10 indicate that the multiple benchmarks are more effective than a single benchmark used to estimating future earnings for positive earnings information. The testing results show that the subject's response to the dependent variable initial estimation of the positive information multiple benchmarks groups had a mean of 586,667 higher than the subject's response to the positive information single benchmark group which have a mean of only 552,222. Results of t-test using independent sample ttest showed $\mathrm{t}$ value of -10.155 and $\mathrm{p}=0.000$. The difference subject's response was statistically significant under one percent $(\mathrm{p}=0.000)$, which means that the subject considering internal, external and time dimension in estimating future earnings. Thus hypothesis 2 is supported.

Table 11

Effectiveness Testing Of Multiple Benchmarks Disclosure Strategy for Negative Information

\begin{tabular}{|c|c|c|c|c|c|c|}
\hline & \multirow[t]{2}{*}{ Mean } & \multirow[t]{2}{*}{$\begin{array}{c}\text { Mean } \\
\text { Difference }\end{array}$} & \multicolumn{2}{|c|}{$\begin{array}{c}\text { Levene's } \\
\text { Test }\end{array}$} & \multicolumn{2}{|c|}{$\begin{array}{c}\text { Independent } \\
\text { T-Test }\end{array}$} \\
\hline & & & $\mathrm{F}$ & Sig. & $\mathrm{t}$ & Sig. \\
\hline $\begin{array}{l}\text { Initial Group: } \\
\text { E+Desc (Negative) vs } \\
\text { E+Desc+IMG (Negative) }\end{array}$ & $483,000>433,889$ & 49,111 & 0.516 & 0.482 & 9.372 & $0.000 *$ \\
\hline $\begin{array}{l}\text { Revised Group: } \\
\text { E+Desc+IMG (Negative) vs } \\
\text { E+Desc+IMG+EMG (Negative) }\end{array}$ & $462,000>399,444$ & 62,556 & 0.627 & 0.439 & 12.020 & $0.000 *$ \\
\hline
\end{tabular}

Note: Significant at 0,05 .

The results of negative earnings information can be described in table 4.9. The testing results show that the subject's response to the dependent variable initial 
estimation of the negative information multiple benchmarks groups had a mean of 433,889 smaller than the subject's response to the negative information single benchmark group which have a mean of 483,000. Results of t-test using independent sample t-test showed $t$ value of 9.372 and $p=0.000$. The difference subject's response was statistically significant under one percent $(\mathrm{p}=0.000)$. These findings indicate that the subject's response with multiple benchmarks is more effective than the single benchmark for positive earnings information only.

\subsubsection{Sensitivity Testing}

Sensitivity testing to give confidence that there is a difference in the group receiving treatment charge information (positive and negative earnings information) and the characteristics of single benchmark information disclosure (earnings, earnings + description) and multiple benchmarks information disclosure (earnings + description + IMG). The sensitivity testing using independent sample t-test for positive and negative charge information and characteristics disclosure strategies can are shown in table 12.

Table 12

Results of Sensitivity Testing

\begin{tabular}{|c|c|c|c|c|c|c|c|}
\hline No & Cell & Event & Strategy & Mean (DS) & $\begin{array}{l}\text { F-test } \\
\text { (sig.) }\end{array}$ & $\begin{array}{l}\text { t-test } \\
\text { (sig.) }\end{array}$ & Notes \\
\hline $\begin{array}{c}\text { Positiv } \\
\text { e } \\
1\end{array}$ & $\begin{array}{c}\text { Information } \\
\vdots \\
\text { Cell 1a } \\
\text { Cell } 2 \mathrm{a}\end{array}$ & $\begin{array}{r}\text { Positiv } \\
\mathrm{e} \\
\text { Positiv } \\
\mathrm{e}\end{array}$ & $\begin{array}{l}\text { Single } \\
\text { Single }\end{array}$ & $\begin{array}{r}538,750 \\
(6,408) \\
552,222 \\
(6,667)\end{array}$ & $\begin{array}{r}0.168 \\
(0.688)\end{array}$ & $\begin{array}{r}-4.245 \\
(0.001)\end{array}$ & Significant \\
\hline 2 & $\begin{array}{l}\text { Cell 2a } \\
\text { Cell 3a }\end{array}$ & $\begin{array}{r}\text { Positiv } \\
\text { e } \\
\text { Positiv } \\
\text { e }\end{array}$ & $\begin{array}{r}\text { Single } \\
\text { Multiple }\end{array}$ & $\begin{array}{r}552,222 \\
(6,667) \\
586,667 \\
(8,876)\end{array}$ & $\begin{array}{r}1.144 \\
(0.298)\end{array}$ & $\begin{array}{r}-10.155 \\
(0.000)\end{array}$ & Significant \\
\hline \multicolumn{8}{|c|}{ Negative Information: } \\
\hline 1 & $\begin{array}{l}\text { Cell 4a } \\
\text { Cell 5a }\end{array}$ & $\begin{array}{l}\text { Negative } \\
\text { Negative }\end{array}$ & $\begin{array}{l}\text { Single } \\
\text { Single }\end{array}$ & $\begin{array}{r}511,000(5,163) \\
483,000 \\
(12,292)\end{array}$ & $\begin{array}{r}6.584 \\
(0.019 \\
)\end{array}$ & $\begin{array}{r}6.641 \\
(0.000)\end{array}$ & Significant \\
\hline 2 & $\begin{array}{l}\text { Cell 5a } \\
\text { Cell 6a }\end{array}$ & $\begin{array}{l}\text { Negative } \\
\text { Negative }\end{array}$ & $\begin{array}{l}\text { Single } \\
\text { Single }\end{array}$ & $\begin{array}{l}483,000 \\
(12,292) \\
433,889 \\
(10,540)\end{array}$ & $\begin{array}{r}0,516 \\
(0.482 \\
)\end{array}$ & $\begin{array}{r}9.372 \\
(0.000)\end{array}$ & Significant \\
\hline
\end{tabular}

Results of testing the sensitivity of the positive and negative earnings information have a significant differenceis below 0.05 . It can be concluded that the 
disclosure strategy hypothesis testing for single and multiple benchmarks supported because each group has a significant difference.

\section{Conclusion, Implication, and Limitation}

This study is aimed to test the impact of single versus multiple benchmarks earnings information disclosure strategy towards financial users' behavior in estimating future earnings. The result indicates that earnings information disclosure strategy of single versus various benchmarks effectively helps investors in predicting future earnings. Further testings suggest that the multiple benchmarks are more effective than a single benchmark used to estimating future earnings for positive earnings information. This finding is consistent with the study conducted by Schrand and Walther (2000), Krische (2005), Han and Tan (2007), and Wahyuni and Hartono (2010, 2012, 2014).

The results provide support that 1) disclosure strategy of the single benchmark (positive or negative information) can influence investor's behavior in estimating future earnings, and 2) disclosure strategy of multiple benchmarks more effective than a disclosure strategy of the single benchmark. The conclusions drawn from empirical findings that support testing of the characteristics of the disclosure include single benchmark strategy hypothesis (H1) and multiple benchmarks strategy hypotheses $(\mathrm{H} 2)$.

Further analysis showed that the disclosure strategy of multiple benchmarks more effective than the disclosure strategy of the single benchmark. Based on the numerous reference theory that states additional information will add more consideration for managers to make better decision making, additional prospectus information is also beneficial for managers. As results, prospectus information as an addition to the historical earnings information will enhance managers' decision making. Therefore, in earnings announcement, when the information of quantitative description of priorperiod gain and management guidance is included in the current-period announcement, investors will evaluate company's performance better than that negative information of additional information.

This research provides theoretical, methodological and policy contributions. Theoretical contribution is the existence of new perception or insight about the 
implementation of multiple reference point theory in strategy disclosure of single versus multiple benchmarks testing. Through empirical testing, this research is expected to give support on multiple reference point theory. As initial research, the research result is expected to trigger next investigations in behavioral aspect of accounting in Indonesia, both in the context of auditing, management accounting, and other fields involving judgment in evaluating company's performance for business decision making.

This research result is expected to show the importance of backward and forwardlooking oriented accounting information which are prior period gain/loss and management guidance information. For the company's management side, this study is expected to be able to introduce and give understanding extensively about prospectus accounting information needed to be disclosed in the earnings announcement. For investors, they are supposed to be able to recognize and to understand the prospectus accounting information that has to be considered in decision making, especially in estimating future earnings, which is backward and forward-looking oriented information. For regulators, this research is expected to be an essential input as a consideration in making Financial Reporting Disclosure Standard. Ikatan Akuntan Indonesia (IAI) or Indonesian Accountant Association (IAA) as the agency of Financial Accounting Standards and Financial Service Authorization also plays a vital role in publishing accounting information and financial reporting disclosure. Therefore, by recognizing and understanding various relevant accounting information for business decision making, as well as information disclosure by company's management along with its multiple effects, it will be beneficial in the process of making, presenting, and disclosing financial reports.

Some improvements need to be done, among others, future research using webbased experiment using computer technology and the Internet. Web-based experiments can simplify management of the subject, setting data, and the process of manipulation, making it possible to test experimental design with complex manipulations. Web-based experimentation is necessary to gain a more representative experimental subject, can generate data at high speed, and can expand participants from various groups with wide geographical distribution. 
Future research more attention to the experimentation design with various tests on its effect. Repeated measurements in within-subject are conducted to anticipate the overflow effects, exercise and transparency effects with using methods counterbalanced methods. Future research is recommended to use different research methods, such as using secondary data with the aim to more in-depth into the usefulness of strategy disclosure of single and multiple benchmarks. Future research needs to distinguish between groups of subjects were professional and non-professional that judgment quality is not only determined by the strategy of disclosure, however contingent with user information as has been recommended Han and Tan (2007).

\section{References}

Ajinkya, B. B. and M. J. Gift. 1984. Corporate Managers, earnings forecasts and symmetrical adjustment of market expectations. Journal of Accounting Research. 22 (2): 425-444.

Baginski, S. P, J. M. Hassell, and M. D. Kimbrough. 2004. Why do managers explain their earnings forecasts? Journal of Accounting Research. 42(March): 1-29.

Bailey, J. 1997. Waste management shares slide after profit warning, disclosures. Wall Street Journal. 13(October): B4.

Bazerman. 1994. Judgment in managerial decision making. Willey \& Sons. Inc.

Bernard, V. L. 1989. Capital markets research in accounting during the 1980's: a critical review. The State of Accounting Research. : 72-120.

Boldt, M. N. 2001. The effects of functional fixation on relative performance evaluation. Academy of Strategic and Organizational Leadership Journal. 5 (1): 17-30

Deogun, N. 1998. Coca-Cola's net income fell by $12 \%$ as global economic crisis hurt sales. Wall Street Journal. 16(October): A4.

Easton, P. and M. Zmijewski. 1989. Cross-sectional variation in the stock market response to accounting earnings announcements. Journal of Accounting and Economics. 11: 117-141.

Fiegenbaum, A. and H. Thomas. 1988. Attitudes toward risk and the risk-return paradox: prospect theory explanations. Academy of Management Journal. 31: 85-106.

S. Hart, and D. Schendel. 1996. Strategic reference point theory. Strategic Management Journal. 17: 219-235.

Foster, G. 1977. Quarterly accounting data: Time-series properties and predictive-ability results. The Accounting Review. 52: 1-21. 
Freeman, R. and S. Tse. 1992. A nonlinear model of security price responses to unexpected earnings. Journal of Accounting Research. 30: 185-209.

Han, Jun. and H. Tan. 2007. Investors 'Reactions to Management Guidance Forms: The Influence of Multiple Benchmarks. The Accounting Review. 82(2): 521-543.

Hartono, Jogiyanto. 2004. How, why and when investors revise their beliefs to company information and their implications to firms announcement policy. ANDI Yogyakarta.

J. and S. Wahyuni. 2014. Implementation of multiple reference point theory in management guidance information disclosure. Unpublished

Hayn, C. 1995. The information content of losses. Journal of Accounting and Economic. 20: 125-153.

Helson, H. 1964. Adaptation Level Theory: An Experimental and Systematic Approach to Behavior. New York, NY: Harper \& Row.

Kahneman, D. and A. Tversky. 1979. Prospect theory: an analysis of decision under risk. Econometrica. 47(March): 263-291.

Kormendi, R. and R. Lipe. 1987. Earnings innovations, earnings persistence, and stock return. Journal of Business. 60: 323-345.

Krische, S. D. 2005. Investor'evaluations of strategic prior-period benchmark disclosure in earnings announcements. The Accounting Review. 80(1): 243-268.

Lowenstein, R. 1997. Sipping the fizzing Coca-Cola's profits. Wall Street Journal (May 1) CI.

Moeckel, Cindy. 1990. The effect of experience on auditor's memory errors. Journal of Accounting Research. 28(2): 368-387.

Ordones, Lisa D., T. Connolly, and R. Coughlan. 2000. Multiple reference points in satisfaction and fairness assessment. Journal of Behavioral Decision Making. 13: 329-344.

Pattel, J. 1976. Corporate forecasts of earnings per share and stock price behavior: Empirical tests. Journal of Accounting Research. (Autumn): 246-276.

Penman, S. 1980. An empirical investigation of the voluntary disclosure of corporate earnings forecasts. Journal of Accounting Research. (Spring): 132-160.

Schrand, C. M. and B. R. Walther. 2000. Strategic benchmarks in earnings announcements: The selective disclosure of prior-period earnings components. The Accounting Review. 75 (2): $151-177$.

Thibaut, J. W., and H. H. Kelly. 1959. The Social Psychology of groups. New York, NY: Willey.

Tversky, A. 1972. Elimination by aspects: A theory of choice. Psychological Review. 79(4): 281-299. 
and D. Kahneman. 1974. Judgment under uncertainty: heuristics and biases. Science. 185: 1124-1131.

Wahyuni, S. and J. Hartono. 2010. Strategic disclosure of multiple benchmarks in earnings announcements: An examination of investor behavior based on internal and external

factors in the performance evaluation. The Indonesian Journal of Accounting Research. 13(Mei): 149-166.

and J. Hartono. 2012. Reminder effect and anchoring-adjustment in earnings announcement. Implementation of prior-period benchmark disclosure strategy. Journal of Indonesian Economy \& Business. 27 (September): 390-405.

Waymire, G. 1984. Additional evidence on the information content of management earnings forecast. Journal of Accounting Research. (Autumn): 703-718. 
The Indonesian Journal of Accounting Research - Sep, Vol. 21 , No.3, 2018

intentionally blank 